\author{
Robert Jop \\ (the State Archive in Lublin, Poland) \\ https://orcid.org/0000-0003-1357-0435 \\ E-mail:weper1467@gmail.com
}

\title{
W sprawie współczesnego edytorstwa staropolskich metryk chrztów. Uwagi do artykułu Tomisława Giergiela, Staropolska Liber baptisatorum jako edycja (stan badań, metody, postulaty), „,Roczniki Humanistyczne” 2020, t. 68, z. 2 , s. $193-215$
}

On the Contemporary Editions of the Old-Polish Baptismal Certificates. Comments on the Article by Tomisław Giergiel, Staropolska Liber baptisatorum jako edycja (stan badań, metody, postulaty), „Roczniki Humanistyczne” 2020, vol. 68, no. 2, pp. 193-215

\section{ABSTRACT}

This article includes polemical remarks on the analysis of the current conditions of editing the Old-Polish baptismal certificates, as was presented by Tomisław Giergiel. The author refers his comments mainly to observations concerning scholarly editions, excluding publications in which the contents of certificates were given in a diversified and popularizing form. This results from the definition of editing - and its flexible treatment - by T. Giergiel. The polemic concerns mainly the major motives of the reviewed

\begin{tabular}{|l|l|l|l|}
\hline \multicolumn{1}{|l|}{ PUBLICATION INFO } \\
\hline
\end{tabular}


article. Additionally, the author presents his own research postulates which are worthy of academic discussion, based on personal experiences with the preparation of parish certificates for publishing. The article by T. Giergiel was assessed as important for the development of knowledge on the contemporary editing of church certificates and a good starting point for the future reflection on the methods of publishing them.

Key words: Old-Polish baptismal certificates, editing, demographic sources

\section{STRESZCZENIE}

Niniejszy artykuł zawiera uwagi polemiczne do analizy stanu współczesnego edytorstwa staropolskich metryk chrztów, przedstawionej przez Tomisława Giergiela. Autor odnosi się w swoich rozważaniach głównie do spostrzeżeń dotyczących edycji naukowych, pomijając wydawnictwa, w których podano treść metryk w urozmaiconej, popularyzatorskiej formie. Wynika to z przyjętej przez T. Giergiela definicji edycji i jej płynnego potraktowania. Polemika dotyczy głównych wątków recenzowanego artykułu. Autor niniejszych rozważań przedstawia ponadto własne postulaty badawcze warte naukowego omówienia, bazując na osobistych doświadczeniach związanych z przygotowaniem metryk parafialnych do druku. Artykuł T. Giergiela został oceniony jako istotny dla rozwoju wiedzy o współczesnym edytorstwie metryk kościelnych i dobry punkt wyjścia do dalszego pogłębiania refleksji w sprawie metod ich wydawania.

Słowa kluczowe: staropolskie metryki chrztów, edytorstwo, źródła demograficzne

Z ogromnym zainteresowaniem przeczytałem artykuł Tomisława Giergiela pt. Staropolska Liber baptisatorum jako edycja (stan badań, metody, postulaty), opublikowany w 68. tomie "Roczników Humanistycznych"1. Notabene wydany w 100 lat po klasycznym dla tematyki metryk parafialnych artykule Kazimierza Dobrowolskiego, dotyczącym ich wartości źródłowych dla badań historycznych ${ }^{2}$. Tekst T. Giergiela pokazuje, jak czas, który dzieli obydwie rozprawy, wpłynął na odbiór i zainteresowanie metrykami historyków i demografów historycznych, odpowiadających tym samym na zawarte w ujęciu K. Dobrowolskiego spostrzeżenia. Zajmujący sposób pisania K. Dobrowolskiego o metrykach, ale też szereg uogólnień, którymi się posłużył w odniesieniu do treści tego typu źródeł, w dużej mierze legły u podstaw pierwszych edycji zapisków metrykalnych, wydawanych jeszcze w okresie międzywojennym ${ }^{3}$. Warto jednak podkreślić, że ustalenia K. Dobrowolskiego w wielu miejscach odbiegają

1 T. Giergiel, Staropolska Liber baptisatorum jako edycja (stan badań, metody, postulaty), „Roczniki Humanistyczne" 2020, 68, 2, s. 193-215.

2 K. Dobrowolski, Znaczenie metryk kościelnych dla badań naukowych, „Rocznik Towarzystwa Heraldycznego" 1920, 5, s. 90-110.

3 Zob. m.in.: W. Budka, Najstarsze metryki kościoła parafialnego w Szreniawie, „Miesięcznik Heraldyczny" 1934, 13, s. 123-124; S. Szczotka, Z dawnych ksiag metrykalnych parafii żywieckiej (1666-1776), „Miesięcznik Heraldyczny” 1937, 16, s. 122-124, 129-136, 148-151, 166-171. Ponadto literatura zgromadzona w: R. Jop, Metryki parafialne wyznania 
od zwyczajnych realiów warstwy informacyjnej metryk przy głębszym rozpoznaniu szczegółowych przypadków, co odnosi się głównie do liczby zapisów kronikarskich, inwentarzy, spisów duchowieństwa itp. wnoszonych do ksiąg.

T. Giergiel w swoim artykule skupił się na dwóch zasadniczych kwestiach. Wskazał na fakt powszechnego udostępniania treści metryk i różnorodnych sposobów realizacji tego zadania. Rzec by można, że $\mathrm{w}$ ujęciu autora metryki trafiły pod strzechy i nie jest to przesada, ale odzwierciedlenie faktów, zważywszy na popularność genealogii wśród szerokiego grona użytkowników zasobów archiwalnych. Jednak poza badaczami zajmującymi się demografią historyczna, metryki staropolskie nie są materiałem tak wykorzystywanym i analizowanym źródłowo, jak na przykład dokumenty czy księgi wpisów i ten fakt odnotujmy z pełną świadomością rangi porównywanych rodzajów dokumentacji. Pod względem dyplomatycznym nie budzi sporów naukowych formularz stosowany w metrykach, nie rozważa się dogłębnie problemów ręki piszącej w kontekście paleograficznym, sporadycznie zwraca się uwagę na budowę ksiąg. Są to oczywiście problemy, które chronologicznie dotyczą głównie średniowiecza, a nie czasów nowożytnych, z których pochodzą metryki, ale jeśli zamiarem autorskim było przedstawienie postulatów badawczych służących rozwojowi wiedzy o tych źródłach, to należało je $\mathrm{w}$ artykule bardziej podkreślić. Niewątpliwie natomiast wartością dodaną ustaleń T. Giergiela jest bogata bibliografia zebranych wydawnictw metryk chrztów, które funkcjonując często jedynie w lokalnym obrocie, są niedostrzegane i nieuwzględniane w szerokim kontekście badań historycznych. Ten wydawniczy ruch zaś - jak wykazał T. Giergiel - jest całkiem prężny i płodny, pomijając odcienie jego metodycznej i metodologicznej wartości. Niewątpliwie podobne naukowe zainteresowanie należy się metrykom ślubów i zgonów.

Niniejsze uwagi polemiczne należy potraktować jako próbę uzupełnienia, rozszerzenia, a w niektórych fragmentach zwrócenia uwagi na odmienną stronę podejścia do edycji metryk parafialnych niż ta, którą przedstawił T. Giergiel. Nie o spór bowiem w nich chodzi, ale o wypracowanie pewnego modelu działań, który by sprawił, że wydawanie metryk można by wznieść na dobry i przystępny dla każdego odbiorcy poziom. Cele edycji tego typu źródeł są bowiem w wielu miejscach rozbieżne i nie mając często punktów wspólnych, recypowane są w zastanej formie. Druga teza, jaka się wobec tego wyłania, zakłada, że istniejące i używane dla wydawnictw źródłowych instrukcje są nazbyt ogólne i nie przystają

rzymskokatolickiego - stan wiedzy i potrzeby badawcze, w: Dyplomatyka staropolska - stan obecny i perspektywy badań, red. W. Chorążyczewski, J. Tandecki, Toruń 2011, s. 143-157. 
do specyfiki przygotowania edytorskiego metryk. Z takim stwierdzeniem koresponduje powstawanie szczegółowych zaleceń w kwestii publikacji indywidualnych typów źródeł, takich jak np. inskrypcje epigraficzne, co T. Giergiel w swoim artykule słusznie odnotował ${ }^{4}$.

Rozważania T. Giergiela skupiają się na pozornie podstawowych problemach edytorstwa metryk. Pozornie podstawowych, bowiem przydałoby się pogłębienie wątków do tej pory w wielu przypadkach pomijanych, a w praktyce wydawniczej istotnych, o czym niżej. Tematycznie artykuł dotyczy tego, jakie powinny być cechy edycji naukowej metryk chrztów, jak sformułowane są tytuły wydawnictw w odniesieniu do podawanej treści oraz jak się ma ich chronologia, a tym samym liczba wydanych wpisów, do możliwości badań w dziedzinie demografii historycznej. Najważniejszą część artykułu stanowią jednak spostrzeżenia odnoszące się do sposobów udostępniania libri baptisatorum i ich opracowania w ramach całego aparatu naukowego stosowanego we wszystkich rodzajach źródeł historycznych. Tekst, wedle tytułowej zapowiedzi, miał uzupełnić postulaty badawcze, ale nie jest ich zbyt wiele, biorąc pod uwagę całość zaprezentowanej problematyki.

W odniesieniu do uwag przedstawionych przez autora artykułu po pierwsze należy zwrócić uwagę na sam przedmiot analizy badawczej, po drugie na skalę i zakres problemów, które rodzą się w trakcie pracy nad edycją ksiąg chrztów, chociaż odnoszą się one w dużej mierze także do innych rodzajów metryk.

W pierwszej kolejności należy odnieść się do tej części uwag, które autor wyznaczył jako przedmiot swojego zainteresowania, stwierdzając, że przez edycję będzie rozumiał „pracę edytorska, która stara się wiernie oddać treść źródła poprzez wydanie go drukiem oraz zaopatrzona jest w aparat naukowy" ${ }^{\prime \prime}$. Tak zakreślone granice T. Giergiel potraktował jednak dosyć płynnie, włączając w krąg swoich naukowych obserwacji szereg innych form podania treści metryk, które tej przyjętej definicji nie odpowiadają. Wyraźny podział owych form jest w tym przypadku niezbędny. Stawiając sprawę wprost, można powiedzieć, że mamy obecnie do czynienia z dwiema przeciwstawnymi grupami wydawnictw: edycjami stricte naukowymi oraz publikacjami, które można by nazwać roboczo hybrydowymi, posiadającymi formę bardzo dowolną w sposobie podania treści metryk chrztów. W pierwszej grupie zasady wydania regulują instrukcje wydawnicze, $\mathrm{w}$ drugiej zasady przyjęte przez wydawcę i na te raczej nie powinno się rozciągać formalnych rygorów edycji klasycznych. W tym punkcie rozważań sprawa dotyczy precyzji

\footnotetext{
T. Giergiel, op. cit., s. 201.

5 Ibidem, s. 194.
} 
terminologicznej i posługiwania się nią w sposób konsekwentny. Kwestia digitalizacji metryk, czy ich indeksacja, o których T. Giergiel mówi jako o sposobie udostępniania treści źródła, jest właśnie przykładem na wspomnianą wyżej płynność potraktowania przedmiotu badań, określonego przez definicję. Czym innym jest bowiem wydanie drukiem metryki, a czym innym udostępnienie informacji w niej zawartych albo całościowo, $\mathrm{np}$. udostępnienie w formie kopii cyfrowych, albo w sposób mniej lub bardziej przetworzonych: tłumaczenia, podanie treści niepełnej, indeksacja, być może także różne zestawienia, które razem wzięte edycjami nie są. Nie trzeba oczywiście wyjaśniać, że edycje klasyczne są jedną z form udostępnienia treści metryk.

Wracając do edycji klasycznych metryk chrztów, należy stwierdzić, że ich specjalne wydzielenie i oddzielenie w analizie od innych rodzajów ksiąg notujących fakt przyjęcia sakramentu nie jest dobrym zabiegiem. Pomijając nawet fakt, że formalnie niejednokrotnie składają się one wraz z zapisami ślubów bądź zgonów na jeden tom, to nie są wyjątkowym źródłem pod względem rejestracji istnienia danej osoby przed osiągnięciem wieku dojrzałego, czyli takiego, który zapewniał zdolność do czynności prawnych ${ }^{6}$. Są tysiące przypadków odnotowanych w księgach ziemskich, grodzkich i miejskich, dających obraz ,usytuowania dziecka w rodzinie, wśród rodzeństwa", jak to określił T. Giergiel. I są one o wiele bardziej wymowne, niż ma to miejsce za przyczyną metryk chrztów. W tej sprawie za równie cenne można uznać metryki zgonów. Jeśli chodzi zaś o liczebność osób odnotowanych w pojedynczych wpisach o udzielonym chrzcie, to nie odbiega ona od tego, co znajdziemy $w$ zapisach metrykalnych ślubów. Trzy rodzaje metryk prowadzonych w parafiach powinny zostać potraktowane wspólnie, bo przecież powstały one nie z naszych, współczesnych potrzeb wyzyskania możliwych źródeł dla prowadzenia takich czy innych badań, ale z faktu istnienia instytucji, której obowiązkiem była rejestracja udzielenia sakramentu. Natomiast ich edycje mają formalnie wiele wspólnych punktów stycznych w procesie przygotowania źródła do druku. Trudno zgodzić się także ze stwierdzeniem, że brak przewagi pracowników naukowych przy edycji metryk wynika z czasu, jaki należy poświęcić temu zadaniu i „niesatysfakcjonującej parametryzacji wydawnictw źródłowych". Chociaż ostatnia konstatacja jest smutnym podkreśleniem niskiej wartości badań naukowych we współczesnej nauce historycznej, czy też naukach humanistycznych w ogóle. Należy raczej zauważyć, omawiając ten problem, że na wielu uniwersytetach kurczy się mocno i szybko warsztat naukowych umiejętności adeptów historii, którzy nie tylko nie radzą sobie z paleografią i łacina, ale trudnością jest

$6 \quad$ Ibidem, s. 193. 
dla nich także krytyczna interpretacja źródła historycznego. Ale to uwaga wykraczająca poza polemikę z tezami T. Giergiela.

Omawiany artykuł to raczej opisanie istniejącego status quo w dziedzinie udostępniania treści metryk parafialnych niż refleksja nad problemem edycji źródła. Część z poczynionych rozważań nad strukturą wydawniczą metryk chrztów jest na tyle oczywista, że zbędną wydaje się być jej analiza. Po cóż bowiem rozważać przykładowo sprawę kompletności podania formularza zapisu metrykalnego $\mathrm{w}$ edycji ${ }^{7}$, skoro przyjęło się zasadę, że ma ona być wiernym odzwierciedleniem oryginału. Przecież każde odstępstwo od niego, wyjąwszy przypadki opisane $\mathrm{w}$ instrukcji wydawniczej, to powód do zarzutu, że nie mamy do czynienia z edycją, ale $\mathrm{z}$ przetworzoną formą źródła podaną $\mathrm{w}$ druku. Być może to podejście zachowawcze lub nawet konserwatywne, ale należy wyraźnie podkreślić, że edycja powinna być wiernym odzwierciedleniem podstawy wydania. Tak to określił również autor artykułu. Nawet zważywszy na powtarzalność formuł stosowanych w zapisach o udzielonych chrztach, $\mathrm{z}$ kancelaryjnego punktu widzenia sprawy, istnienie takiego procesu jest wskazówką do sformułowania określonych wniosków. Inaczej sprawę można by zredukować do indeksacji metryk, niewątpliwie przydatnej, ale ograniczającej i nieoddającej wszelkich niuansów treści źródła. Tym bardziej jeśli zastosuje się do niej wprost, bez żadnej subtelności wykazania owych odcieni, najnowsze systemy elektroniczne. Takie traktowanie sprawy może kłóci się z dotychczasowym, unifikującym w podejściu do edycji źródła zastosowaniem instrukcji wydawniczych, np. w wydaniu Kazimierza Lepszego, ale jest w nich szczęśliwie furtka pozwalająca na wprowadzanie własnych rozwiązań edytorskich, więc trzeba z niej korzystać pełną garścią.

Każda edycja ma swój układ opisany przez instrukcję wydawniczą. W przypadku metryk staropolskich wydawcy powołują się zazwyczaj na instrukcję opracowaną przez K. Lepszego i wydaną w końcu lat pięćdziesiątych XX w. ${ }^{8}$ Już sam fakt, że od jej powstania upłynęło z górą sześćdziesiąt lat powoduje, że anachronizmem staje się kurczowe jej trzymanie, przede wszystkim ze względu na postęp możliwości technicznych w edytorstwie, do których instrukcja nie przystaje. Niemniej w odniesieniu do układu wydawnictw źródłowych wydaje się być ona niezagrożona. Edycje metryk chrztów, jak też dwóch ich pozostałych rodzajów: ślubów i zgonów, składają się - mówiąc w uproszeniu - z trzech części: wstępnej, treści źródła i indeksów (skorowidzów, jak nazwał to

\footnotetext{
7 Ibidem, s. 201.

8 Instrukcja wydawnicza dla źródet historycznych od XVI do połowy XIX wieku, oprac.
} K. Lepszy, Wrocław 1953. 
K. Lepszy). W każdej z nich mamy do czynienia z osobnymi problemami przygotowania wydawnictwa, co T. Giergiel zauważył, ale niektórych zagadnień nie pogłębił w swoim wywodzie.

Jeśli chodzi o część wstępną, to największym problemem jest pokusa jej rozbudowania o analizę treści źródła z całkowitym lub częściowym pominięciem jego analizy źródłoznawczej. Być może to jest punkt wyjścia do powstawania tak różnorodnych form udostępniania informacji zawartych w metrykach. Fascynacja nazwiskami ochrzczonych, szafarzy sakramentów, świadków itd., możliwość układania z nich zestawień, wykresów i tabel przeważają nad żmudną analizą formularza i cech zewnętrznych księgi metrykalnej. Tymczasem analiza źródłoznawcza powinna być $\mathrm{w}$ centrum zainteresowania wydawcy, czego historycy zajmujący się demografią historyczną lub genealogią czasami nie rozumieją oczekując gotowych rozwiązań wynikających z metryk. Nie do wydawcy jednak należą zestawienia, chociaż może je sporządzić poza edycją metryki, ale do jej adresata, posiadającego odpowiednie narzędzia i kwalifikacje, któremu edytor ułatwia dostęp do treści źródła. Chęć popularnego potraktowania źródła nie powinna w związku z tym być dominująca nad zawężeniem grupy odbiorców edycji metryk do grona znawców zagadnienia. Także dlatego, że obecnie możliwości dostępu do ksiąg metrykalnych w postaci elektronicznej są coraz większe.

Wyjaśnić należy jeszcze kwestię, którą T. Giergiel w swoim artykule błędnie zinterpretował. Podstawa wydania to nie jest powód bądź przyczyna działań zmierzających do edycji źródła9 . To jest fizyczny obiekt, którego treść została oddana w druku i której cechy zewnętrzne zostały opisane przez wydawcę. W przypadku metryk parafialnych podstawa wydania jest zazwyczaj jedna. Jest nią oryginalna księga, powstała współcześnie do opisywanych w niej zdarzeń. Jedna, oryginalna księga, bowiem $\mathrm{w}$ okresie staropolskim nie praktykowano $\mathrm{w}$ parafiach prowadzenia wtóropisów, tak jak z powodów administracyjnych w okresie późniejszym. Natomiast chcąc mówić o decyzjach kierujących wydawcami przy wyborze metryk do wydania, to są one z pewnością podyktowane m.in. ich stanem zachowania, zarówno liczbowym, ogólnym lub w danej kategorii w parafii, jak też stanem fizycznym i stopniem zniszczenia. Z pewnością też przy wyborze księgi do wydania decydują indywidualne preferencje wydawcy.

Część druga edycji, czyli publikacja źródła, to sprawa jasna. Nie podlega dyskusji, że zgodnie z zasadami wydanie metryki powinno mieć formę in extenso. Wszelkie dywagacje na ten temat $i$, jak wyżej powiedziano, analizowanie różnych jego wariantów nie mają uzasadnienia. Cytowanie

9 T. Giergiel, op. cit., s. 204. 
przez T. Giergiela wyjaśnień, że publikacja w druku powtarzających się formuł zwiększa objętość wydania edycji ${ }^{10}$, jest niezrozumieniem problemu przez cytowanych i powinno się je skwitować odpowiednim komentarzem. Do rozstrzygnięcia i jednoznacznego ustalenia pozostają natomiast kwestie numeracji wpisów przez wydawcę, w tym rodzajów wpisów, które powinny jej podlegać, oraz oddania w edycji formy prezentacji informacji zastosowanej w źródle (wpisy następujące w ciągu lub zastosowanie tabeli). W pierwszym przypadku za numeracją przemawiają względy praktyczne. Jej zastosowanie ułatwia tworzenie indeksów oraz późniejszą identyfikację haseł przez odbiorcę. Z drugiej strony numeracja nie jest częścią składową wpisu, więc jej wprowadzenie kłóci się z zasadami wydawniczymi. Sprawa komplikuje się, zważywszy na fakt, że instrukcja wydawnicza zaleca wprowadzenie do treści edytowanego źródła informacji o numerach kart lub stron, na których znajdują się wpisy, więc ten element może być wystarczający do wspomnianej identyfikacji. Ten sposób postępowania rozwiązywałby kwestię, czy numerować tylko wpisy o udzielonych sakramentach, czy również inne, np. dotyczące wizytacji, listy dobrego urodzenia, dyspensy od przepisanej liczby zapowiedzi, kronikarskie, czyli ogólnie mówiąc, wykraczające poza treść merytoryczną księgi.

W przypadku drugim mamy do czynienia na przykład z metrykami wojnickimi, powstałymi po I rozbiorze Polski, czyli w czasie, gdy wprowadzono austriacki, tabelaryczny sposób zapisu aktów ${ }^{11}$. Słuszne spostrzeżenie w tej sprawie poczynił T. Giergiel, wskazując na pomieszanie wariantów wydawania metryk i zastosowanie tabel tam, gdzie ich nie ma i na odwrót ${ }^{12}$. Biorąc pod uwagę edycje naukowe, nie ma chyba żadnych przeciwstawieństw do tego, by w wydaniu trzymać się formy oryginału, czemu sprzyjają posiadane współcześnie narzędzia. Wymaga to wprawdzie większego nakładu pracy od osoby przygotowującej edycję od strony technicznej, ale jest możliwe do wykonania. Zachowanie przekazu treści metryki w formie oryginału jest korzystne także dla odbiorcy. Wprowadza ład w narracji i daje możliwość szybkiego odnalezienia wpisu oraz identyfikacji osób w nim występujących. Generalnie bowiem formularz posttrydencki staje się bardziej kompletny i jednoznaczny co do przekazu informacji.

Sporządzenie indeksów do metryk chrztów oraz innych, to najbardziej czaso- i pracochłonna część wydania źródła drukiem. Instrukcja

10 Ibidem, s. 201 i n.

11 Metryki kolegiaty św. Wawrzyńca w Wojniczu 1675-1784, t. 8, Liber baptisatorum 17771784, wyd. T. Giergiel, J. Szymański, B. Trelińska, Wojnicz 2017.

12 T. Giergiel, op. cit., s. 202-203. 
wydawnicza K. Lepszego nie podaje szczegółowych rozwiązań co do sposobów ich przygotowania. Należy więc podkreślić, że o ile w przypadku kodeksów dyplomatycznych przy niewielkiej liczbie osób odnotowanych $\mathrm{w}$ dokumentach i przy innych czynnikach związanych ze sposobami rejestracji wystawców, stron sprawy lub świadków czynności prawnej, indeksacja jest $\mathrm{w}$ miarę prosta, to metryki reprezentują $\mathrm{w}$ tej sprawie skalę masową. Inaczej mówiąc, indeksy metrykalne, szczególnie do ksiąg chrztów i ślubów, obejmują kilka, a nawet kilkanaście tysięcy osób. Trudno identyfikowalnych i w tym tkwi cały problem tworzenia do nich skorowidzów.

Z wywodu T. Giergiela wynika, że w odniesieniu do omawianej kwestii mamy do czynienia $\mathrm{z}$ różnorodnymi metodami przygotowania indeksów. W publikacjach pozanaukowych przypominają one czasem skorowidze XIX-wieczne, obejmujące hasłami kilka tomów edycji różnych ksiąg $^{13}$, inne są emanacją zastosowania najnowszych baz danych ${ }^{14}$ lub polegają na powiązaniu jednostek w kontekście społecznym, co raczej należy traktować jako opracowanie materiału źródłowego niż proste indeksowanie jego wydania. Stąd dla publikacji naukowych zasadniczą staje się kwestia czytelności i jasnych kryteriów tworzenia skorowidzów. Szczególnie w przypadku indeksów osobowych, bowiem przy indeksach nazw geograficznych i rzeczowych, jeśli wydawca zdecyduje się na ich ułożenie, zasady są jasne i prostsze.

Pytań o zasady tworzenia indeksów osobowych jest wiele. Czy indeksowanie powinno polegać na zmodernizowaniu bądź sprowadzeniu do jednego wzoru danego nazwiska zapisanego w różnych odmianach? Jakie kryteria przyjąć przy identyfikacji osób i tym samym w ilu wariantach je rejestrować? Czy wydawcę powinno zajmować odróżnianie osób o tym samym imieniu i nazwisku (powtarzalność osób) z racji spełnianej funkcji? Czy decydować ma sam fakt występowania osoby o tym samym imieniu i nazwisku, a więc przyjęcie kryterium formalnego, w którym wydawca daje pole do samodzielnej identyfikacji uczestników zdarzenia przez odbiorcę edycji? To są tylko niektóre problemy oczekujące na rozwiązanie $\mathrm{w}$ trakcie pracy nad wydawnictwem. Rozstrzygnięcia $\mathrm{w}$ tej sprawie będą decydowały między innymi o możliwości prowadzenia badań antroponomastycznych na podstawie metryk, ale także o objętości tego typu wydawnictw, żeby sprawę sprowadzić tylko do wynikających $\mathrm{z}$ tego kwestii ekonomicznych. Zdarzają się bowiem sytuacje, w których rozbudowane indeksy osobowe dorównują objętością samej edycji.

13 Ibidem, s. 205-206.

14 Ibidem, s. 207. 
Identyfikacja osób i wzór tworzenia indeksu na podstawie podziału na nupturienta i świadka aktu zawarcia małżeństwa, o którym pisze T. Giergiel, odwołując się do metryk wojnickich ${ }^{15}$, to jeden $\mathrm{z}$ dobrych sposobów postępowania. Niemniej niewystarczający dla okresu staropolskiego, $\mathrm{w}$ obliczu wielokrotnego wchodzenia w związki sakramentalne. $\mathrm{W}$ wymienionej grupie przypadków oraz w zapisach o chrztach dzieci jeszcze więcej komplikacji rodzi masowość występowania chrzestnych i świadków, których może być w odniesieniu do pojedynczych wpisów powyżej dwóch przepisanych. Ich właściwe rozpoznanie jest często niemożliwe, co powoduje, że osobę o imieniu $X$, pochodzącą $z$ miejscowości $Y$, musimy odnotować kilkakrotnie w formie osobnych haseł. Dochodzą do tego przykłady, w których z powodu uszkodzenia karty czy niedostatecznej możliwości odczytu nazwiska, staje się ono niekompletne, rodząc pytanie o umiejscowienie $\mathrm{w}$ indeksie osobowym. Jest to szczególnie trudne, gdy brak dotyczy początku nazwiska, nie dając możliwości przyporządkowania go do danej litery alfabetu. Wypracowanie metod postępowania w opisanych, jedynie przykładowo podanych przypadkach, czy to na podstawie rozwiązań praktycznych, czy formalnych, a więc zestandaryzowanych, to praca do wykonania dla wydawców edycji naukowych. Albo w ramach osobnych instrukcji wydawniczych, albo rozwiązań indywidualnych autora publikacji. Generalnie bowiem chodzi o to, jak daleko wydawca przy tworzeniu indeksów osobowych może ingerować w treść źródła.

Na zakończenie niniejszych rozważań, odstępując od przyjętej w tym artykule zasady polemiki w sprawie sposobów wydawania edycji naukowych metryk chrztów, kilka uwag należy poświęcić niepogłębionemu przez T. Giergiela zagadnieniu dołączania do publikacji kopii cyfrowych metryk, jako swego rodzaju pakietu wydawniczego. Odłóżmy przy tym na bok banały o pogodzeniu interesów odbiorców wprawionych i niewprawionych $\mathrm{w}$ odczycie treści metryk ${ }^{16}$. Historyk o wystarczających umiejętnościach paleograficznych, jeśli ma dostęp do oryginału księgi, poradzi sobie z nią bez edycji. Jeśli dostępu nie ma, edycja będzie dla niego jedynie ułatwieniem w dotarciu do treści źródła, więc kopia cyfrowa metryki stanie się zbędna, tym bardziej że na jej podstawie nie będzie mógł określić cech zewnętrznych księgi. Niewprawiony, bez odpowiedniego przetworzenia i przygotowania $\mathrm{w}$ duchu popularyzacyjnym informacji znajdujących się w zapisach metryki, często nie poradzi sobie z samą edycja, a tym bardziej z jej oryginałem.

Problem leży w związku z tym gdzieś indziej. Zwróćmy w tej sprawie uwagę przede wszystkim na podłoże stanowiące o możliwościach dostępu 
zainteresowanych do metryk kościelnych. Ciągle są one związane z miejscem przechowywania ksiąg znajdujących się w głównej mierze w archiwach (kancelariach) parafialnych pod opieką proboszczów. Ci zaś, czasem $\mathrm{z}$ powodu ambiwalentnego stosunku do nich - choć $\mathrm{w}$ tej sprawie widać znaczący postęp - ale bardziej z przyczyn stricte technicznych, w pierwszym przypadku nie chca, $\mathrm{w}$ drugim nie mają możliwości udostępnienia ksiąg, czy to poprzez bezpośredni kontakt z nimi, czy też udostępnienie $\mathrm{w}$ celu zeskanowania albo po prostu $\mathrm{w}$ formie kopii cyfrowych. Jeżeli tę sytuację porównamy do postępowania z XIX-wiecznymi aktami stanu cywilnego, to stwierdzimy, że ich masowa indeksacja i publikacja indeksów w Internecie wynika nie tyle ze specyfiki ich formularza czy języka treści zapisów, co z ich powszechnej dostępności w archiwach państwowych lub na portalach internetowych, które te instytucje prowadzą. W związku z tym wydaje się, że gdyby tak samo dostępne były metryki parafialne, nie byłoby problemu z podjęciem $\mathrm{w}$ odniesieniu do nich podobnych działań, dzięki czemu zakres możliwości edytorskich i badawczych w dziedzinie genealogii oraz indeksacji znacząco by się powiększył.

Inicjatywy dołączania do publikacji kopii cyfrowych ksiąg metrykalnych pojawiają się głównie $\mathrm{w}$ ich popularnych wydaniach i niewątpliwie zabieg ten ma w pierwszej kolejności służyć zilustrowaniu prezentowanych treści. Być może w pewnym stopniu chodzi dodatkowo o podniesienie prestiżu i poziomu naukowości takich wydań, a nawet usprawiedliwienie poczynionych zmian w treści źródła i zwrócenie uwagi, że oryginał księgi wygląda zupełnie inaczej niż przedstawia to publikacja. Niewątpliwie jednak digitalizacja każdej staropolskiej metryki parafialnej to dobry sposób na jej udostępnienie, ale także na zachowanie archiwaliów, które jak wyżej powiedziano, niejednokrotnie traktowane są przez proboszczów jako zbędnie zalegające w archiwum parafialnym, kłopotliwe i niepotrzebne ${ }^{17}$. W tym kontekście dołączanie skanów metryk do publikacji jest okazją do zachowania dziedzictwa dokumentacyjnego powstałego $\mathrm{w}$ okresie staropolskim i jednocześnie weryfikacji zasobów archiwów parafialnych. Natomiast nie wydaje się, aby publikowanie kopii cyfrowych wybranych zapisów metryk w edycjach naukowych miało charakter instruktażowy, jak o tym napisał T. Giergiel ${ }^{18}$. Każdy z edytowanych zapisów spełnia tę funkcję, ukazując różnorodność formularza wpisów, więc należy je bardziej traktować jako prezentację wybranych

17 Z tego powodu projekty pokroju realizowanego przez Piotra Rachwała z Katolickiego Uniwersytetu Lubelskiego, zmierzające do całościowej digitalizacji metryk parafii wchodzących w skład danej diecezji, są poza celem naukowym, szczególnym przykładem troski o ich zachowanie. Zob. http://www.ksiegimetrykalne.pl/zrodla [dostęp: 25 VII 2020].

18 T. Giergiel, op. cit., s. 202. 
przykładów interesujących ze względu na cechy owego formularza lub szczegóły treści.

Niewątpliwie rozpatrzenie całości problemów związanych z ruchem wydawniczym dotyczącym metryk chrztów, ale też innych serii ksiąg rejestrujących życie religijne wiernych w okresie staropolskim, to okazja do osobnego i obszernego artykułu, jeśli nie konferencji, która zebrałaby różne głosy w omówionej sprawie. Problemów do zbadania i analizy jest w tym przypadku wiele, począwszy od rozstrzygnięć w sprawach podstawowych, czyli jak skomponować poszczególne części edycji metryki, a skończywszy na postulacie przygotowania odrębnej instrukcji wydawniczej dla tego rodzaju źródeł. Artykuł T. Giergiela jest dobrym wstępem do dyskusji, wskazującym na obszary badawcze do zagospodarowania przez znawców problematyki. Od czasu ich refleksji nad tymi zagadnieniami będzie zależała zatem jakość naszych wydawnictw metryk parafialnych.

\section{REFERENCES (BIBLIOGRAFIA)}

\section{Printed sources (Źródła drukowane)}

Metryki kolegiaty św. Wawrzyńca w Wojniczu 1675-1784, t. 8, Liber baptisatorum 1777-1784, wyd. T. Giergiel, J. Szymański, B. Trelińska, Wojnicz 2017.

\section{Studies (Opracowania)}

Budka W., Najstarsze metryki kościoła parafialnego w Szreniawie, „Miesięcznik Heraldyczny” $1934,13$.

Dobrowolski K., Znaczenie metryk kościelnych dla badań naukowych, „Rocznik Towarzystwa Heraldycznego" 1920, 5.

Giergiel T., Staropolska Liber baptisatorum jako edycja (stan badań, metody, postulaty), „,Roczniki Humanistyczne" 2020, 68, 2.

Instrukcja wydawnicza dla źródeł historycznych od XVI do połowy XIX wieku, oprac. K. Lepszy, Wrocław 1953.

Jop R., Metryki parafialne wyznania rzymskokatolickiego - stan wiedzy i potrzeby badawcze, w: Dyplomatyka staropolska - stan obecny i perspektywy badań, red. W. Chorążyczewski, J. Tandecki, Toruń 2011.

Szczotka S., Z dawnych ksiag metrykalnych parafii żywieckiej (1666-1776), „Miesięcznik Heraldyczny" 1937, 16.

\section{NOTA O AUTORZE}

Robert Jop - absolwent kierunku historia (specjalność archiwistyczna) w Uniwersytecie Marii Curie-Skłodowskiej w Lublinie. Doktorat na podstawie rozprawy Środowiska urzędnicze kancelarii grodzkich w Chetmie, Lublinie i Krasnymstawie w II połowie XVII w. w 2001 r. W latach 2002-2015 adiunkt w Zakładzie Nauk Pomocniczych Historii i Bibliotekoznawstwa UMCS. Od 2015 r. zatrudniony w Archiwum Państwowym w Lublinie, gdzie pracuje obecnie jako starszy archiwista w Sekcji prac naukowych i wydawniczych oraz popularyzacji. Zainteresowania badawcze to dyplomatyka staropolska, genealogia, geografia historyczna oraz historia prawa i urzędów I Rzeczypospolitej. 